\title{
Preparation and characterization of biodegradable films from keratinous wastes of the leather industry
}

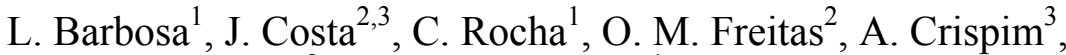 \\ C. Delerue-Matos ${ }^{2} \&$ M. P. Gonçalves ${ }^{1}$ \\ ${ }^{I}$ REQUIMTE, Faculdade de Engenharia, Universidade do Porto, \\ Portugal \\ ${ }^{2}$ REQUIMTE, Instituto Superior de Engenharia do Porto, Portugal \\ ${ }^{3}$ CIETI, Instituto Superior de Engenharia do Porto, Portugal
}

\begin{abstract}
With increasing demand for sustainable materials, keratin wastes have been regarded, in recent years, as renewable resources worthy of exploitation. Each year, the Portuguese leather industry discards a considerable amount of animal hair, which constitutes a troublesome waste product. In this study, in an attempt to find a potential utilization for this waste, the preparation of biodegradable films from bovine hair, by thermo-compression, was tested. Bovine hair formulations with 20,30 and $40 \mathrm{wt} \%$ of plasticizer (glycerol, lactic acid) were pressed into films, at $147 \mathrm{kN}$ and $120^{\circ} \mathrm{C}$ or $160^{\circ} \mathrm{C}$ for 4 minutes. The mechanical properties, colour, solubility and water sorption isotherms of the obtained films were assayed. All films were opaque and dark. Solubility was higher for films processed at higher temperature and with lactic acid as plasticizer. The Guggenheim-Anderson-de Boer (GAB) model gave a good fit to the experimental results for the moisture sorption isotherms. The stress at break, $\sigma$, and the Young's modulus, E, decreased and the strain at break, $\varepsilon$, increased with the addition of increasing amounts of plasticizer.

Keywords: bovine hair, keratin, film, thermo-compression, mechanical properties, solubility, water sorption isotherms.
\end{abstract}




\section{Introduction}

Leather industry has been considered as one of the highly polluting industries with an inevitable negative environmental impact. Processing hides and skins and converting them into leathers is characterized by a huge amount of liquid and solid wastes [1].

Large-scale production systems are adopted for leather processing in clusters and therefore, the industry receives focus of environmentalists and society. Consequently tremendous pressure is exerted by various pollution regulatory organisms [2].

The production in the Portuguese Leather Industry is roughly 100 million square feet per year. The main production is cattle leather with about $80 \%$ of the total production, $15 \%$ for sheep, and $5 \%$ for goats, horses, buffaloes and others [3].

The introduction of cleaner technologies, in order to generate a minimum of residues is urgent. Several alternatives to the conventional process have been studied. The liming process with hair recovery allows the hair removal from the skin without any damage; moreover it decreases the organic load and the production of solid wastes, which can be used as by-products [4].

Bovine hair is composed of over $90 \%$ protein, the main component being keratin, a fibrous and insoluble protein highly cross-linked with numerous intermolecular disulphide and other bonds [5]. Several reports described the preparation of films by casting the reduced keratin solution after mixing with chemical crosslinkers such as ethylene glycol diglycidyl ether and glycerol diglycidyl ether [6-8].

A thermal processing is a different way to produce films and it has advantages compared with the previously one like this technique is simpler and environmentally friendly [9].

The aim of this work was to explore the possibility to use bovine hair wastes of Portuguese leather industry as a source of keratin for film production by thermo-compression. The hair waste containing keratin was ground and modified with glycerol or lactic acid, which acted as a plasticizer. The granulometry of the hair and the quantity of plasticizer were optimized. Films were prepared by pressing the modified keratin at typical polymer processing temperatures. The resulting films were tested to determine the effect of processing conditions and plasticizer addition on their water solubility and water sorption isotherms and on their mechanical properties.

\section{Materials and methods}

\subsection{Preparation of bovine hair}

Bovine hair samples were provided by the Portuguese industry Curtumes Aveneda. Hair was removed from the bovine skin using Hair-Saving process [10]. Most commercial systems for hair-save unhairing are based on immunisation. Immunisation can be achieved by using sodium hydroxide, lime 
or calcium hydroxide; it usually takes 1-1.5 hours. The developed work consists in the addition of commercial calcium hydroxide solution $(1 \%(\mathrm{w} / \mathrm{w})$, for 1 hour), allowing the removal of hair without damage, during the liming process in the leather industry.

After this processing, the hair was filtered, dried at $60^{\circ} \mathrm{C}$ and subsequently it was milled (ZM 200, Retsch, Germany) and sieved (AS 200, Retsch, Germany) for 30 minutes to a final particle size of less than $50 \mu \mathrm{m}$. This granulometry was selected because in previous studies it was observed that, for particle size less than $50 \mu \mathrm{m}$, the films were more flexible and less brittle [11].

Samples were characterized with respect to parameters such as humidity, percentage of organic matter and mineral content, fat content and Kjeldahl nitrogen.

\subsection{Film preparation}

Ground bovine hair was mixed with different ratios $(20-40 \mathrm{wt} \%)$ of plasticizer (glycerol or lactic acid) in a mortar during $~ 30$ minutes, at room temperature. These plasticizer ratios were chosen to compare with other studies in the literature on keratin films [12]. Following mixing, $1.5 \mathrm{~g}$ of sample was distributed evenly in a circular mold with $5 \mathrm{~cm}$ of diameter. The moulded sample was sandwiched between aluminium foil and pressed into film in a Carver Press Autofour/15P (model 25-12HC, Carver, Inc., Wabash, USA), at $147 \mathrm{kN}$ and $120^{\circ} \mathrm{C}$ or $160^{\circ} \mathrm{C}$ for 4 minutes. These conditions were established based on preliminary tests. After pressing, the film was removed and allowed to cool till room temperature.

Film thickness was measured at five different points on each film using a thickness comparator (Absolute Digimatic Indicator, model ID-F150, Mitutoyo Co., Japan) with a resolution of $1 \mu \mathrm{m}$. Reported thickness values are means of the five measurements.

Samples for testing were cut from the films and conditioned at $23 \pm 2{ }^{\circ} \mathrm{C}$ and $53 \%$ relative humidity for at least $48 \mathrm{~h}$.

\subsection{Colour}

Film colour was determined by a Minolta colorimeter CR300 series (Tokyo, Japan) using the CIELab parameters; lightness ( $\left.\mathrm{L}^{*}\right)$ and chromaticity parameters $-a^{*}$ (red - green) and $b^{*}$ (yellow - blue) - were measured. At least five independent measurements for each condition were tested at room temperature and humidity.

\subsection{Solubility}

The film solubility (\%) in water was defined as the ratio of water-soluble solids, after $24 \mathrm{~h}$ immersion in water, to the initial solids content [8].

The specimens for this test were cut with an area of $1.5 \times 1.5 \mathrm{~cm}^{2}$ and, after conditioning, were weighed and placed in Erlenmeyer flasks with $20 \mathrm{ml}$ of distilled water, which were sealed with parafilm and kept at $25^{\circ} \mathrm{C}$. After the 
assay, these films and original films were dried at $105^{\circ} \mathrm{C}$ to constant weight for determination of solids content. At least three replicates of each film were tested and film solubility was calculated as the average value of the measurements.

\subsection{Water sorption isotherms}

Water sorption isotherms were determined by the gravimetric method. Pre-dried samples with dimensions of $1.5 \times 1.5 \mathrm{~cm}^{2}$ were placed in desiccators with different relative humidity $(\mathrm{RH})$, imposed by the use of saturated salt solutions (Table 1), for $\mathrm{a}_{\mathrm{w}}$ ranging from 0.11 to 0.90 . The experiment was carried out at $25^{\circ} \mathrm{C}$. Values for the water activity of the salt solutions at $25^{\circ} \mathrm{C}$ were obtained from the literature $[13,14]$.

Table 1: $\quad$ Saturated salt solutions used to control relative humidity in desiccators.

\begin{tabular}{|c|c|c|}
\hline Salt & $\begin{array}{c}\text { Chemical } \\
\text { formula }\end{array}$ & $\begin{array}{c}\text { Water activity, } \mathrm{a}_{\mathrm{w}} \text {, of the saturated } \\
\left.\text { salt solution (at } 25^{\circ} \mathrm{C}\right)\end{array}$ \\
\hline Lithium chloride & $\mathrm{LiCl}$ & 0.112 \\
\hline Magnesium chloride & $\mathrm{MgCl}_{2}$ & 0.328 \\
\hline Potassium carbonate & $\mathrm{K}_{2} \mathrm{CO}_{3}$ & 0.432 \\
\hline Magnesium nitrate & $\mathrm{Mg}\left(\mathrm{NO}_{3}\right)_{2}$ & 0.529 \\
\hline Sodium bromide & $\mathrm{NaBr}$ & 0.576 \\
\hline Strontium choride & $\mathrm{SrCl}$ & 0.709 \\
\hline Sodium choride & $\mathrm{NaCl}$ & 0.753 \\
\hline Barium choride & $\mathrm{BaCl}_{2}$ & 0.902 \\
\hline
\end{tabular}

The samples were weighed periodically, using a balance Sartorius BP211D (Sartorius AG, Germany) with a resolution of $0.01 \mathrm{mg}$, until they reached constant weight, after which their moisture content was determined by the gravimetric method. The Guggenheim-Anderson-de-Boer (GAB) model, eqn. (1) [15], was used to fit experimental sorption data:

$$
X e=\frac{X m(C k a w)}{(1-k a w)(1-k a w+C k a w)}
$$

where $X_{e}$ is the equilibrium moisture content on a dry weight basis at the water activity $a_{w}, X_{m}$ is the monolayer moisture content on a dry weight basis and represents the water content corresponding to saturation of all primary adsorption sites by one water molecule, $C$ is the Guggenheim constant and represents the energy difference between the water molecules attached to primary sorption sites and those adsorbed to successive sorption layers and $k$ is the corrective constant taking into account properties of multilayer molecules with respect to the bulk liquid. 
GAB equation parameters were calculated using non-linear estimation, QuasiNewton method, with the software StatSoft, Inc - STATISTICA, version 6.0.

\subsection{Mechanical properties}

Mechanical properties of the films were evaluated in a texture analyser (TA.XT2, Stable Micro Systems, Surrey, UK) equipped with tensile test attachments, using five replicates. The test specimens consisted of strips of uniform width and length $\left(1.5 \times 6.0 \mathrm{~cm}^{2}\right)$, corresponding to $60 \%$ of the recommended size (ASTM D882) [16].

The distance between the grips was $4.0 \mathrm{~cm}$ and the applied test speed was 0.1 $\mathrm{cm} / \mathrm{min}$, while force $(\mathrm{N})$ and deformation (\% strain) were recorded.

The Young's modulus, E, was calculated from the initial linear part of the stress-strain curve. Tensile strength was calculated as the stress at break $(\sigma)$ of the specimen and elongation at break $(\varepsilon)$ was expressed as the percent change of the original length of the specimen between the grips of the texture analyser.

These tests were run immediately after removing the specimens from the desiccators, to minimize adsorption/desorption of water by them.

\section{Results and discussion}

For all the tested conditions, cohesive films were obtained with variable diameter $(5.9-8.5 \mathrm{~cm})$ and thickness $(0.22-0.46 \mathrm{~mm})$. These two parameters varied inversely, as expected. Higher diameters and lower thicknesses were observed for films plasticized with glycerol (Fig. 1). For both plasticizers used, higher diameters and lower thicknesses were observed when the protein/ plasticizer ratio or the processing temperature was increased.

\subsection{Colour}

All films were opaque and dark. However, films with lactic acid were lighter (higher $\mathrm{L}^{*}$ values) than films with glycerol (Fig. 1).

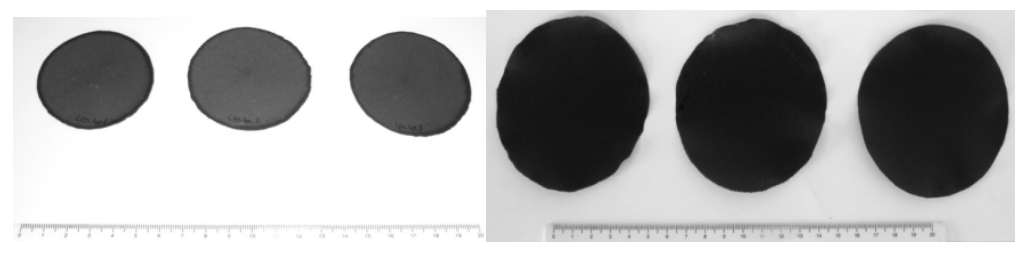

Figure 1: Films obtained by thermo-compression of ground bovine hair mixed with lactic acid (left) or glycerol (right).

Colour parameters $\left(\mathrm{L}^{*}, \mathrm{a}^{*}\right.$ and $\left.\mathrm{b}^{*}\right)$ decreased when processing temperature increased (Fig. 2). No pronounced differences were observed by changing the amount of plasticizer added. 

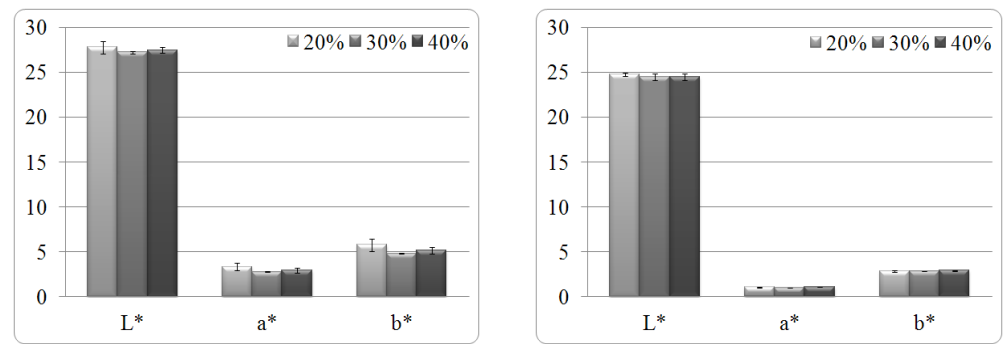

Figure 2: Colour parameters for films formed with glycerol at $120^{\circ} \mathrm{C}$ (left) and $160^{\circ} \mathrm{C}$ (right).

\subsection{Solubility}

Films solubility results are shown in table 2 . In general, water solubility was higher for films processed at higher temperature and with lactic acid as plasticizer. The solubility increased also with the amount of added plasticizer (glycerol or lactic acid). Probably, the addition of plasticizer prevented the formation of -S-S- bridges on keratin films or interfered with other interactions like hydrogen bonding, electrostatic and hydrophobic bonds, resulting in an increase of solubility. Besides, both plasticizers are hydrophilic so it is expected that film solubility increases when their amount in the film formulation increases.

Table 2: $\quad$ Solubility of bovine hair films.

\begin{tabular}{|c|c|c|c|}
\hline \multirow{2}{*}{$\mathrm{T}\left({ }^{\circ} \mathrm{C}\right)$} & \multirow{2}{*}{$\%$ Plasticizer } & \multicolumn{2}{|c|}{ Solubility (\%) } \\
\cline { 2 - 4 } & & Glycerol & Lactic acid \\
\hline \multirow{3}{*}{120} & 20 & $8.6 \pm 2.9$ & $15.5 \pm 0.1$ \\
\cline { 2 - 4 } & 30 & $10.0 \pm 2.1$ & $18.8 \pm 0.2$ \\
\cline { 2 - 4 } & 40 & $13.2 \pm 3.4$ & $20.6 \pm 0.2$ \\
\hline \multirow{3}{*}{160} & 20 & $13.6 \pm 0.7$ & $17.4 \pm 0.2$ \\
\cline { 2 - 4 } & 30 & $15.4 \pm 0.3$ & $21.0 \pm 0.3$ \\
\cline { 2 - 4 } & 40 & $28.6 \pm 0.1$ & $25.5 \pm 0.1$ \\
\hline
\end{tabular}

The addition of glycerol produced a smoother, more homogeneous film surface than that produced with lactic acid which probably contributes for the lower solubility of those films.

The solubility values obtained in this study were lower than those reported in previous studies on keratin [8] or fish myofibrillar proteins [17] films produced by casting.

\subsection{Water sorption isotherms}

Moisture sorption isotherms for films with different plasticizer concentrations were obtained. In general, they presented a sigmoid shape, as shown in fig. 3, 


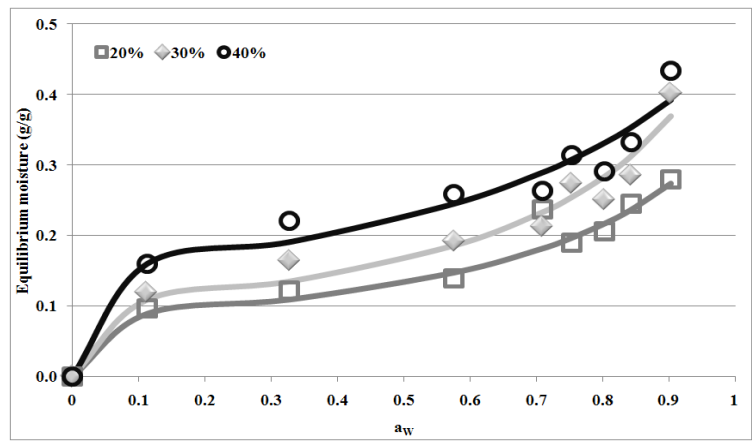

Figure 3: Water sorption isotherms for films processed with lactic acid, at $120^{\circ} \mathrm{C}$. Lactic acid concentration (wt \%): $20(\square), 30(\diamond)$ and $40(\circ)$.

indicating that the equilibrium moisture content, $X_{e}$, increased slowly with $a_{w}$ up to 0.7 , beyond which a steep rise in $X_{e}$ was observed.

The GAB parameters and the correlation coefficients for films processed with lactic acid or glycerol, at different plasticizer concentrations and processing temperatures, are presented in table 3. Values of $\mathrm{C}>5.67,0.24<\mathrm{k}<1$ and the correlation coefficient $\mathrm{R}>0.98$ show that the $\mathrm{GAB}$ equation gives a good fit to the experimental data.

In general, the moisture sorption isotherms were influenced by the concentration and type of plasticizer (Table 3). Higher levels of plasticizer increased the films water sorption (Fig. 3) and these results could be attributed to the hydrophilicity of the plasticizers, which presented hydroxyl groups capable of interacting with water by hydrogen bonds.

Table 3: $\quad$ GAB parameters for bovine hair films.

\begin{tabular}{|c|c|c|c|c|c|c|}
\hline \multicolumn{2}{|c|}{ GAB Parameters } & $\mathrm{C}$ & $\mathrm{k}$ & $\mathrm{Xm}$ & $\mathrm{R}$ & Temperature \\
\hline \multirow{4}{*}{ Glycerol } & $20 \%$ & 612502 & 0.947 & 0.075 & 0.989 & \\
\cline { 2 - 6 } & $30 \%$ & 1205028 & 0.892 & 0.093 & 0.974 & \\
\cline { 2 - 6 } & $40 \%$ & 1732215 & 0.867 & 0.105 & 0.971 & \multirow{2}{*}{$120^{\circ} \mathrm{C}$} \\
\hline \multirow{4}{*}{ Lactic acid } & $20 \%$ & 2749025 & 0.778 & 0.081 & 0.995 & \\
\cline { 2 - 6 } & $30 \%$ & 2069602 & 0.810 & 0.099 & 0.977 & \\
\cline { 2 - 6 } & $40 \%$ & 496485 & 0.691 & 0.147 & 0.976 & \\
\hline \multirow{5}{*}{ Lactic acid } & $20 \%$ & 120 & 0.874 & 0.093 & 0.991 & \multirow{2}{*}{$160^{\circ} \mathrm{C}$} \\
\cline { 2 - 6 } & $30 \%$ & 50 & 0.635 & 0.192 & 0.993 & \\
\cline { 2 - 6 } & $40 \%$ & 71 & 0.761 & 0.141 & 0.941 & \\
\cline { 2 - 6 } & $40 \%$ & 2500911 & 0.783 & 0.090 & 0.980 & \\
\hline
\end{tabular}




\subsection{Mechanical properties}

The amount of plasticizer (glycerol or lactic acid) influenced the mechanical properties of the films. The stress at break, $\sigma$, and the Young's modulus, E, decreased and the strain at break, $\varepsilon$, increased with the addition of increasing amounts of plasticizer (Table 4 and Fig. 4). In other words, the films became more ductile with the addition of plasticizer (in the concentration range studied). This behaviour is in accordance with the results obtained for thermally processed keratin from poultry feathers [12].

Table 4: $\quad$ Mechanical properties for bovine hair films.

\begin{tabular}{|c|c|c|c|c|c|}
\hline Plasticizer & $\begin{array}{c}\% \\
\text { Plasticizer }\end{array}$ & $\mathrm{T}\left({ }^{\circ} \mathrm{C}\right)$ & $\begin{array}{c}\text { Stress at } \\
\text { Break, } \sigma \\
(\mathrm{MPa})\end{array}$ & $\begin{array}{c}\text { Young's } \\
\text { Modulus, E } \\
(\mathrm{MPa})\end{array}$ & $\begin{array}{c}\text { Strain at } \\
\text { Break, } \varepsilon \\
(\%)\end{array}$ \\
\hline \multirow{6}{*}{ glycerol } & \multirow{2}{*}{$20 \%$} & 120 & $4.43 \pm 1.20$ & $9.51 \pm 0.49$ & $0.49 \pm 0.14$ \\
\hline & & 160 & $8.48 \pm 1.10$ & $11.49 \pm 0.72$ & $0.81 \pm 0.15$ \\
\hline & \multirow{2}{*}{$30 \%$} & 120 & $4.20 \pm 0.62$ & $9.19 \pm 0.58$ & $0.48 \pm 0.11$ \\
\hline & & 160 & $3.82 \pm 0.35$ & $3.53 \pm 0.78$ & $2.12 \pm 0.26$ \\
\hline & \multirow{2}{*}{$40 \%$} & 120 & $3.78 \pm 0.91$ & $8.91 \pm 0.70$ & $0.44 \pm 0.07$ \\
\hline & & 160 & $3.02 \pm 0.2$ & $3.49 \pm 0.10$ & $1.65 \pm 0.14$ \\
\hline \multirow{6}{*}{ lactic acid } & \multirow{2}{*}{$20 \%$} & 120 & $6.22 \pm 0.37$ & $10.47 \pm 0.14$ & $0.60 \pm 0.05$ \\
\hline & & 160 & $9.50 \pm 0.44$ & $21.50 \pm 0.89$ & $0.47 \pm 0.05$ \\
\hline & \multirow{2}{*}{$30 \%$} & 120 & $4.78 \pm 0.38$ & $9.57 \pm 0.27$ & $0.52 \pm 0.03$ \\
\hline & & 160 & $6.74 \pm 0.72$ & $11.32 \pm 0.19$ & $0.61 \pm 0.08$ \\
\hline & \multirow{2}{*}{$40 \%$} & 120 & $2.89 \pm 0.23$ & $7.82 \pm 0.08$ & $0.39 \pm 0.03$ \\
\hline & & 160 & $5.40 \pm 0.43$ & $9.64 \pm 0.23$ & $0.65 \pm 0.06$ \\
\hline
\end{tabular}

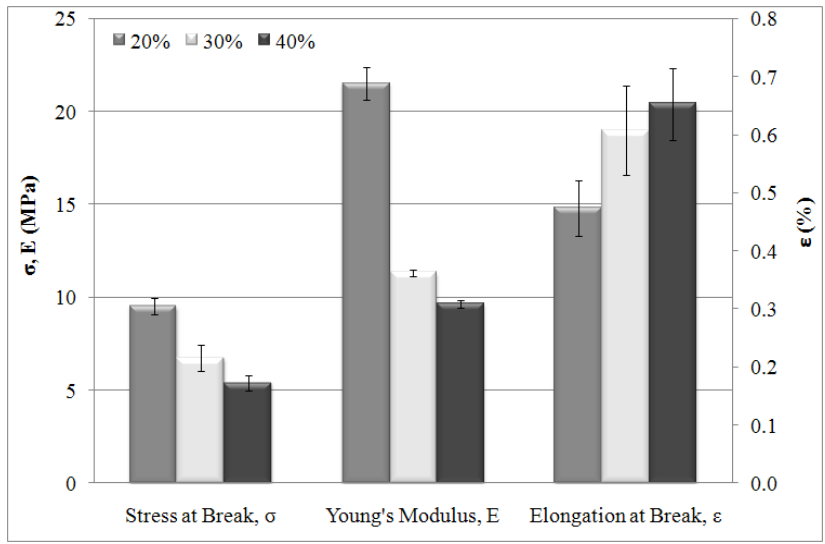

Figure 4: $\quad$ Mechanical properties of films with lactic acid processed at $160^{\circ} \mathrm{C}$. 
Ductility also increased for films processed with glycerol (30\% and 40\%) when the processing temperature increased from $120^{\circ} \mathrm{C}$ to $160^{\circ} \mathrm{C}$. The reverse was observed for films processed with $20 \%$ lactic acid that became more brittle.

Maximum values of $\sigma=9.50 \pm 0.44 \mathrm{MPa}$ and $\mathrm{E}=21.50 \pm 0.89 \mathrm{MPa}$ were obtained for films with $20 \%$ lactic acid, processed at $160^{\circ} \mathrm{C}$ (Fig. 4).

\section{Conclusions}

The results of the present work show that it is possible to obtain cohesive films from bovine hair by thermo-compression. This method is easy, quick and environmentally friendly because no solvents, oxidising or reducing agents are needed as often described in literature for the preparation of keratin films by other techniques such as casting.

The addition of a plasticizer at different levels modified the mechanical properties of the films meaning that it is possible to control the stiffness and rigidity of the films by varying the amount of plasticizer added. Films exhibited low water solubility when compared with other protein-based films described in the literature. This is an important result regarding the possible application of these films in food packaging or for agricultural uses.

\section{Acknowledgements}

Thanks are due to QREN (Quadro de Referência Estratégica Nacional), Fundo Europeu de Desenvolvimento Regional (EU) and AdI (Agência de Inovação) for financial support to FILMEQUE project: Development of keratin films from waste poultry feathers and bovine hair (SI IDT - 5551/2009 AdI) and for grants to L. Barbosa and J. Costa and to Curtumes Aveneda for providing the raw material.

\section{References}

[1] Kanagaraj, J., Velappan, K.C., Babu N.K.C. \& Sadulla, S., Solid wastes generation in the leather industry and its utilization for cleaner environment - A review. Journal of Scientific \& Industrial Research, 65, pp. 541-548, 2006.

[2] Sundar, V.J., Gnanamani, A., Muralidharan, C., Chandrababu, N.K. \& Mandal, A.B, Recovery and utilization of proteinous wastes of leather making: a review. Reviews in Environmental Science and Biotechnology, Springer, 2010. (DOI 10.1007/s11157-010-9223-6)

[3] APIC- Associação Portuguesa dos Industriais de Curtumes, Social \& Environmental Report of the Portuguese Leather Industry, 2010.

[4] Ludvík, J., The scope for decreasing pollution load in leather processing, United Nations Industrial Development Organization (UNIDO), Buljan, J. (Project Manager), US/RAS/92/120/11-51, Regional Programme for 
Pollution Control in the Tanning Industry in South-East Asia, Agro-Industries and Sectorial Support Branch, 2000.

[5] Lynch, M.H., O’Guin, W.M., Hardy, C., Mak, L., \& Sun, T.T., Acidic and basic hair/nail ("'hard") keratins: their co-localization in upper cortical and cuticle cells of the human hair follicle and their relationship to "soft" keratins. Journal of Cell Biology, 103, pp. 2593-2606, 1986.

[6] Tanabe, T., Okitsu, N. \& Yamauchi, K., Fabrication and characterization of chemically crosslinked keratin films. Materials Science \& Engineering: C: Biomimetic and Supramolecular Systems, 24, pp. 441-446, 2004.

[7] Fujii, T., Ogiwara, D. \& Arimoto, M., Convenient procedures for human hair protein films and properties of alkaline phosphatase incorporated in the film. Biological \& Pharmaceutical Bulletin, 27, pp. 89-93, 2004.

[8] Moore, G. R. P., Martelli, S. M., Gandolfo, C., Sobral, P. J. A. \& Laurindo, J. B., Influence of the glycerol concentration on some physical properties of feather keratin films. Food Hydrocolloids, 20, pp. 975-982, 2006.

[9] Barone, J.R \& Arikan O., Composting and biodegradation of thermally processed feather keratin polymer. Polymer Degradation and Stability, 92, pp. 859-867, 2007.

[10] Frendrup, W., Hair-Save Unhairing Methods in Leather Processing, United Nations Industrial Development Organization (UNIDO), Buljan, J. (Project Manager), US/RAS/92/120, Regional Programme for Pollution Control in the Tanning Industry in South-East Asia, Agro-Industries and Sectorial Support Branch, 2000.

[11] Pitrez, P.R., Costa, J., Rocha, C., Freitas, O.M., Crispim, A., Delerue-Matos, C. \& Gonçalves, M.P., The effect of granulometry, glycerol concentration and presence of fat in the properties of films from feathers and bovine hair. Macro2010- 43 ${ }^{\text {rd }}$ IUPAC World Polymer Congress, Glasgow, UK, 11-16 July, 2010.

[12] Barone, J. R., Schmidt, W. F. \& Liebner, C. F. E., Thermally Processed Keratin Films. Journal of Applied Polymer Science, 97, pp. 1644-1651, 2005.

[13] Greenspan, L., Humidity fixed points of binary saturated aqueous solutions. Journal of Research of the Natural Bureau of Standards, 81A, pp. 89-96, 1977.

[14] Spiess, W.E.L. \& Wolf, W.R., The results of the COST 90 Project on water activity. In: Jowitt, R., (Ed.). Physical properties of food, Applied Science Publishers, London, pp. 65-87, 1983.

[15] Van der Berg, C., Description of water activity of foods for engineering purposes. In: B.M. McKenna (Ed.), Engineering and food, Elsevier Applied Science, New York, pp. 311-321, 1984.

[16] ASTM D882 - "Standard Test Method for Tensile Properties of Thin Plastic Sheeting", Annual Book of ASTM Standards, Vol 08.01, 2009.

[17] B. Cuq, N. Gontard, J-L. Cuq \& S. Guilbert, Selected functional properties of fish myofibrillar protein-based films as affected by hydrophilic plasticizers. Journal of Agricultural and Food Chemistry, 45, pp. 622-626, 1997. 